\title{
The Anti-Sartre? Michel Houellebecq and Politics
}

\begin{abstract}
In his writings and other public interventions, Michel Houellebecq has never hidden his contempt for Jean-Paul Sartre and the pretentions of the intellectuel engagé. In his fiction and poetry there can be found a process of de-politicisation that accelerates across the generations, accompanied by an embrace of, or resignation to, the global market economy. However, politics has never been completely absent from Houellebecq's work, while he has not hesitated to make public interventions in the form of articles and interviews. This essay proposes to explore the relationship between Houellebecq and politics, in all its variety: communism, euroscepticism, conservatism; his "projet pour la France" set out in the Houellebecquian décor of Lui magazine, his reactions to recent terrorist attacks, his abstentionism during the 2017 Presidential elections, etc. What is the politics of Houellebecq? Is there/can there be a Houellebecquian engagement?
\end{abstract}

\section{Text}

Jean-Paul Sartre is sometimes mentioned in critical studies of Michel Houellebecq. Douglas Morrey writes: "No French author has achieved such global visibility since Jean-Paul Sartre and Albert Camus. Not only that, but Houellebecq is commonly regarded as the single most controversial writer France has produced since Louis-Ferdinand Céline". ${ }^{1}$ Perry Anderson argues that Houellebecq is the only French writer since Sartre with significant national and international "public authority". ${ }^{2}$ But Sartre is usually invoked in order to bemoan, with often a strong hint of nostalgia, what might, as for Schlomo Sand, constitute "the end of the French

\footnotetext{
${ }^{1}$ Douglas Morrey, Michel Houellebecq. Humanity and its Aftermath, (Liverpool: Liverpool University Press, 2013), p. 1.

2 Perry Anderson, 'Dégringolade', London Review of Books, 26, 17, 2 September 2004, pp. 3-9.
} 
intellectual". ${ }^{3}$ For Anderson, "the days of Malraux are long gone". ${ }^{4}$ For Carole Sweeney, Houellebecq offers a cultural pessimism served up in "a monotonous, often inconsistently textured, drone that seems fitting to ring in the greyish political tenor of twenty-first century France (...) The France of which Houellebecq speaks here is, of course, ideologically a world away from that of Camus and Sartre, where Right and Left were clearly defined in an oppositional, often acrimonious, relationship". ${ }^{5}$ Indeed, Sweeney asserts that Houellebecq's writing is the very antithesis of Sartre's concept of littérature engagée defined most clearly in his 1947 essay Qu'est-ce que la literature?: “by his own repeated admission, Houellebecq has no interest in involving himself in the world, politically, textually or otherwise; indeed, each of his novels considered here depicts, in one way or another, an inching away from the world and its vicissitudes". ${ }^{6}$

It is certainly the case that, in his fiction and essays, Houellebecq has shown contempt for Sartre and the "universal intellectual" he came to represent. In Les Particules élémentaires, Janine Ceccaldi, mother of the main protagonists Bruno and Michel, could, while a medical student in Paris, “vivre d'assez près les années 'existentialistes', et eut même l'occasion de danser un be-bop au Tabou avec Jean-Paul Sartre. Peu impressionnée par l'œuvre du philosophe, elle fut par contre frappée par la laideur de l'individu, aux confins du handicap, et l'incident n'eut pas de suite". ${ }^{7}$ When, in La Carte et le territoire, Houellebecq describes his coke-snorting libertine friend Frédéric Beigbeder as "une sorte de Sartre des années 2010 ", he is humorously pointing to significant ideological and attitudinal changes in the intellectual hot-house of Saint-Germain-des-Prés: Beigbeder's interventions include "ses positions courageuses en faveur de la légalisation de la drogue et de la création d'un statut

\footnotetext{
${ }^{3}$ Shlomo Sand, La Fin de l'intellectuel francais? De Zola a Houellebecq (Paris : La Découverte, 2016).

${ }^{4}$ Anderson, p. 3.

${ }^{5}$ Carole Sweeney, Michel Houellebecq and the Literature of Despair (London: Bloomsbury, 2013), p. 8.

${ }^{6}$ Ibid., p. 10.

${ }^{7}$ Michel Houellebecq, Les Particules élémentaires (Paris: J'ai lu, 2000), pp. 26-27.
} 
des prostitués". ${ }^{8}$ In his short theoretical essay, "Sortir du XXe siècle", Houellebecq excoriates three of the great French intellectuals of the mid-twentieth century:

Quand on se remémore l'ignorance scientifique crasse d'un Sartre et d'une Beauvoir, pourtant supposés s'inscrire dans le champ de la philosophie, quand on considère le fait presque incroyable que Malraux a pu - ne fût-ce que très brièvement être considéré comme un grand écrivain, on mesure le degré d'abrutissement auquel nous sera menés la notion d'engagement politique. ${ }^{9}$

Sartre is also targeted in Houellebecq's 2002 essay "Europe Endless", where the author of Les Mains sales is seen as illustrating a moribund gauche morale's self-hatred and desire to disappear: "Que Sartre ait été animé, à titre personnel, d'une intense rage de disparaître, on peut le comprendre ; on peut même, éventuellement, compatir”. Houellebecq goes on to argue that France will disappear into a greater European agglomeration, and, with that, will disappear the committed intellectuals he so derides : "la 'gauche morale française' ne sera bientôt plus qu'un souvenir. On pourra se la remémorer à travers le théâtre de Genet et Sartre, le cinéma de Bernard-Henri Lévy ou de Romain Goupil, les interventions de Pierre Bourdieu, les chroniques de Jean Baudrillard ; au moins, ce ne sera pas un souvenir écrasant". ${ }^{10}$

But the self-loathing Houellebecq attributes to Sartre and his imitators also extends to the author himself: “Je n'aime pas ce que je suis en train de faire ; au fond, j'ai toujours détesté l'idée que les écrivains prennent des positions politiques; je trouve cela indigne, irrespectueux du lecteur". ${ }^{11}$ Indeed, "Europe Endless" is a rambling and oblique intervention

\footnotetext{
${ }^{8}$ Houellebecq, La Carte et le territoire (Paris: Garnier-Flammarion, 2016), p. 150.

${ }^{9}$ Houellebecq, Lanzarote et autres textes (Paris : J'ai lu, 2002), p. 74.

${ }^{10}$ Houellebecq, "Europe Endless", (published online in 2002), p. 6.

${ }^{11}$ Ibid., p. 6.
} 
in the 2002 presidential campaign, which concludes on a call for a vote for Jean-Pierre Chevènement, paradoxically candidate of the eurosceptic left. This Internet intervention was not an isolated example of Houellebecq expressing political opinions, contrary to Agnès Poirier's assertion, in her hostile review of Shlomo Sand's book, that Houellebecq only makes pronouncements when he has books to sell. ${ }^{12}$ Granted, in his fiction and poetry, there can be discerned a process of de-politicisation that accelerates across the generations, accompanied by an embrace of, or resignation to, the global market economy. However, politics has never been completely absent from Houellebecq's work, while he has not hesitated to make public interventions in the form of articles and interviews. This essay will explore the relationship between Houellebecq and politics, and investigate the possibility of Houellebecquian engagement.

\section{The Failure of Altruism: Houellebecq and Communism}

Houellebecq critics have rarely taken into account his relationship with Communism. Yet his serious break as a writer came when, in 1988, his poems were accepted by Michel Bulteau, director of La Nouvelle Revue de Paris. Houellebecq would then join Bulteau on the editorial committee of Digraphe, an avant-garde review close to the French Communist Party, founded by Louis Aragon's lover and executor, the poet Jean Ristat. Houellebecq would contribute to another of Ristat's ventures, the revived journal Les Lettres françaises, notably with the acerbic "Jacques Prévert est un con". That said, Ristat's initiative came in the fateful year of 1989: Houellebecq was compagnon de route of a rapidly paling shadow of the party Sartre had gravitated towards forty years previously. And, after the deindustrialisation of the Mitterrand years, there was no more Boulogne-Billancourt Renault factory to désespérer.

\footnotetext{
${ }^{12}$ Agnès Poirier, "Is there no end to books on 'the end of France' ?”, The Spectator, 21 April 2018.
} 
In his essay, “Approches du desarroi”, Houellebecq sets out a quasi-Marxian analysis of contemporary society and a literary response to it. For the author of Les Particules élémentaires, liberalism has extended the domain of struggle from economic to personal relationships: each individual is urged, through peer pressure, advertising and media, to succeed and consume conspicuously in the social hypermarket. In the erotic economy, the body itself has become quantifiable and, according to each individual's personal measurements, is accorded exchange value. Houellebecq inhabits a world where le libéralisme has extended the domain of struggle from economic to personal relationships. In le système libéral, we are free to compete and consume conspicuously in the social hypermarket, to consume and be consumed, thanks to our more or less agreeable personal measurements, or to be left on the shelf. Just as in eastern Germany after the fall of the Berlin Wall, there are no guarantees in the liberal sexual system, no right to work or minimum wage: love has its own beggars and homeless. Houellebecq thus comes across as a fin de siècle Karl Marx of the lonely.

Liberalism, continues Houellebecq, triumphantly proclaiming the end of History, displays an arrogance shared by Christianity and totalitarian ideologies. There are, however, possibilities of resisting this liberal 'becoming'. An example was the large 'No' vote in the Maastricht referendum of September 1992. Further back in the recent past is the upheaval of May 1968 . Houellebecq is naturally opposed to the ideology of that year, which was merely an exacerbation of liberalism: “Mai 68 n'a servi qu'à briser les quelques règles morales qui entravaient la voracité de son fonctionnement."13 However, has a fond childhoos memory of how the strikes of that year briefly paralysed a relentless social machine: "la succession

\footnotetext{
${ }^{13}$ Houellebecq, Interventions (Paris: Flammarion, 1998), p. 78.
} 
operationnelle de l'échange sexuel, de l'aventure et de la lassitude se trouva d'un seul coup brisée." 14

The nature of writing and reading, by its subjective and slow nature, also resists the liberal becoming: "De toutes ses forces, (qui furent grandes) la littérature s'oppose à la notion d'actualité permanente, de perpétuel présent. " 15 On the wasteland of the contemporary liberal system, literature can still eke out an existence: "La littérature s'arrange de tout, s'accommode de tout, fouille parmi les ordures, lèche les plaies du malheur. Une poésie paradoxale, de l'angoisse et de l'oppression, a donc pu naître au milieu des hypermarchés et des immeubles de bureaux. " ${ }^{16}$ Literature can contribute to a more general movement of opting out of the liberal system: "Chaque individu est (...) en mesure de produire en lui-même une sorte de révolution froide, en se plaçant pour un instant en dehors du flux informatifpublicitaire. C'est très facile à faire; il n'a même jamais été aussi simple qu'aujourd'hui de se placer, par rapport au fonctionnement du monde, dans une position esthétique: Il suffit de faire un pas de côté. "17

We can see in "Approches du desarroi” Houellebecq's strong affinities with the thought of Arthur Schopenhauer: life as an eternally aimless and insatiable striving, inseparably united with misery and misfortune, liberation from such misery being found through art and altruism. ${ }^{18}$ In political terms, this can be seen in Houellebecq's refusal of the materialist dialectic as well as of literature at the service of revolution. Returning to his quasiMarxian critique of contemporary society, Houellebecq also displays the influence of Situationist theory as expounded by Guy Debord and Raoul Vaneigem: the extension of commodification to all domains of everyday life; the "présent perpétuel" and "spectacle généralisé" driven by "le flux informatif-publicitaire"; the desire to overcome all separations.

\footnotetext{
14 Ibid., p. 78.

${ }^{15}$ Ibid., p. 75 .

${ }^{16}$ Ibid., p. 79.

${ }^{17}$ Ibid., p. 80.

${ }^{18}$ See also Houellebecq, En présence de Schopenhauer (Paris : L’Herne, 2017)
} 
However, the libertarian hedonism advocated by Vaneigem's Traité de savoir-vivre à l'usage des jeunes générations is stark in its absence, as is the council communism imagined by Debord in La Société du spectacle. Attached to stillness and silence, and with an acute aversion to violence, Houellebecq is not proposing mass revolutionary action in the traditional sense. The revolution proposed by Houellebecq is froide and quietist, with a central role played by literature, an activity which the Situationists had sought to supersede along with other art-forms.

Houellebecq's conception of literature also contrasts sharply with Sartre's as expounded in Qu'est-ce que la littérature?. "Je crois peu en la liberté”, he declared to Revue perpendiculaire at the time of the publication of Les Particules élémentaires, thus precipitating his expulsion from its editorial board. ${ }^{19}$ Nor does he share Sartre's rigid distinction between a prose that signifies and discloses the outside world and "l'attitude poétique qui considère les mots comme des choses et non comme des signes". ${ }^{20}$ Indeed, Sartre's distinction between art-forms hardly applies to Houellebecq, who has excelled as poet, novelist, essayist, photographer, and, to a lesser extent, rap artist, film maker and actor. The virtuoso range of genres in Houellebecq's novels - from poetry to pornography via science and detective fiction - further problematises Sartre's generic distinctions, although, in Sartrean terms, Houellebecq could be seen as aiming for a particular kind of "total literature". Indeed, he goes much further than Sartre's proposal, in Qu'est-ce que la littérature?, that writers seek a wider public through journalism and cinema.

In contrast with Sartre as well as the Situationists, poetry and the poet are championed in Houellebecq's pugnacious "method", Rester vivant. According to this manifesto, "le monde est une souffrance déployée", and the poet is peculiarly sensitive to this unbearable

\footnotetext{
19 “'Je crois peu en la liberté', Revue Perpendiculaire, 11, (1998), p. 8.

${ }^{20}$ Jean-Paul Sartre, Qu'est-ce que la littérature? (Paris : Gallimard, 1948), p. 18.
} 
truth. ${ }^{21}$ Parental neglect and sexual humiliation reinforce the extreme sensibility of the poet. The discordance between the real and the ideal must be welcomed and cultivated: "apprendre à devenir poète, c'est désapprendre à vivre". ${ }^{22}$ But this timid social monster, full of resentment and the object of pity and contempt, must avoid the obvious "solution" of suicide : "un poète mort n'écrit plus d'où l'importance de rester vivant". ${ }^{23}$ He must hold firm and articulate suffering in poetic form. A sacred parasite, he will live off wealthy friends, while avoiding too noisy neighbours, and endeavour to leave a minimum of poems for editorial posterity. The Houellebecquian poet may have chosen the margins and eschewed political engagement: “le militantisme rend heureux, et vous n'avez pas à être heureux”. ${ }^{24}$ But he is nevertheless "la partie sombre" of society as a whole ${ }^{25}$. His words convey the awful truth that happiness does not exist, that love solves all problems but cannot truly be found. Poetic emotion articulates the neurosis of a moribund civilisation.

The miserable existence of this suicidé vivant permeates Houellebecq's poems. This abject individual, precariously sustained by anti-depressants and alcohol, is "en système libéral/Comme un loup dans un terrain vague". ${ }^{26}$ Tortured by "l'insupportable retour des minijupes", imprisoned in his decaying body and two metre-long mattress, a thirtysomething man, who already feels old, contemplates slashing his wrists while remembering childhood "la lande était douce à mes pieds" - and a crushed illusion : "Avant, il y a eu l'amour ou sa possibilité". ${ }^{27}$

But this "lone wolf" is not alone in being alone in the liberal system. A descent into the streets of Paris confirms this : "Les humains sous leur parapluie/Cherchent une porte de

\footnotetext{
${ }^{21}$ Houellebecq, Rester vivant (Paris: Editions de la Différence, 1991), p. 11.

22 Ibid, p. 14.

${ }^{23}$ Ibid, p. 29.

${ }^{24}$ Ibid, pp. 42-43.

${ }^{25}$ Ibid, p. 43.

${ }^{26}$ Houellebecq, Poésies (Paris: J'ai lu, 2004), p. 36.

${ }^{27}$ Ibid., pp. 35, 54 and 56.
} 
sortie/Entre la panique et l'ennui/(Mégots écrasés dans la boue) $" .{ }^{28}$ A sense of defeat and decline fills the benighted citizens of the Ville Lumière: "Certains de nos désirs ont construit cette ville/Nous avons combattu des puissances hostiles,/Puis nos bras amaigris ont lâché les commandes". ${ }^{29}$ There remains a pathetic, almost Pétainist, desire for "une paix sans victoire". ${ }^{30}$ And yet, in the midst of solitude and suffering, there is striving for a solution. Carole Sweeney uses exclusively Houellebecq's fiction to illustrate the "end of affect" in his neoliberal universe. But, as Agathe Novak-Lechevalier points out, his poetry seeks to "proscrire l'affectation et retrouver l'affect". 31 "Le sens du combat" has not been completely lost : “ j'ai tenu bon, mon frère”. ${ }^{32}$ In the pantheon of Houellebecquian heroes, Joseph Stalin is joined by Maximilien de Robespierre, who had insisted that "fraternité" be added to the motto of the French Republic. There is still the hint of a possibility that the losers of the social hypermarket will join forces.

In 1996, Houellebecq told Les Inrockuptibles that in his verse there was "une nostalgie presque militante de l'élan révolutionnaire", while doubting his own aptitude for life in a communist society : “Tout en étant hostile à l'individualisme, j'ai été fortement marqué par mon époque, aussi. Je suis aussi individualiste et indifférent aux autres que n'importe qui. Par ailleurs, j'ai peur des mouvements collectifs. Je pense qu'une bande ou une foule est toujours abjecte" ${ }^{33}$. This was further expounded in an interview with L'Humanité. Houellebecq was hardly a Proletkult author: "Mes personnages ne sont ni riches, ni célèbres ; ce ne sont pas non plus des marginaux, des délinquants ni des exclus"34. What's more, he was "communiste mais non marxiste" :

\footnotetext{
${ }^{28}$ Ibid., p. 34.

${ }^{29}$ Ibid., p. 204.

${ }^{30}$ Ibid., p. 144.

${ }^{31}$ Agathe Novak-Lechevalier, « Là où ça compte », in Houellebecq, Non réconcilié (Paris: Poésie/Gallimard, 2014), p. 15.

${ }^{32}$ Poésies, p. 108.

33 “J'ai que des doutes", Les Inrockuptibles, 4 April 1996, pp. 58-59.

${ }^{34}$ Interventions, p. 115.
} 
L'erreur du marxisme a été de s'imaginer qu'il suffisait de changer les structures économiques, que le reste suivrait. Le reste, on l'a vu, n'a pas suivi. Si par exemple les jeunes Russes se sont si rapidement adaptés à l'ambiance répugnante d'un capitalisme mafieux, c'est que le régime précédent s'était montré incapable de promouvoir l'altruisme. S'il n'y est pas parvenu, c'est que le matérialisme dialectique, basé sur les mêmes prémisses philosophiques erronées que le libéralisme, est par construction incapable d'aboutir à une morale altruiste. ${ }^{35}$

Houellebecq has repeatedly expressed an aversion to political militancy. Refuting accusations by Daniel Lindenberg of being a "new reactionary"36, and espousing a conservatism that would have made him Pétainist in 1940 and a defender of the Soviet Union in 1991, he wrote in Le Figaro magazine that "l'homme révolté, le résistant, le patriote" would appear to the conservative as "des individus méprisables, mus par la stupidité, la vanité et le désir de violence." ${ }^{\prime 37}$ This disdain is echoed in La Carte et le territoire, where the fictional Houellebecq reads out to Jed Martin this withering assessment by Alexis de Tocquevelle, author of De la démocratie en Amérique - "sans doute le livre politique le plus intelligent jamais écrit" - of poet-revolutionary Lamartine: "il est le seul, je crois, qui m’ait semblé toujours prêt à bouleverser le monde pour se distraire". ${ }^{38}$ Unlike Sartre, the only petition Houellebecq has ever signed was in 2017, calling for Michel Déon, his late, estranged friend, to have the right to burial in Paris.

Political commitment also has a very marginal presence in Houellebecq's fiction. In Extension du domaine de la lutte, current affairs are something that atomised individuals

\footnotetext{
${ }^{35}$ Ibid, pp. 119-120.

${ }^{36}$ Daniel Lindenberg, Le Rappel à l'ordre. Enquête sur les nouveaux réactionnaires (Paris : Seuil, 2002).

${ }^{37}$ Houellebecq, "Le conservatisme, source de progrès", Le Figaro magazine, 8 November 2003, p. 40.

${ }^{38}$ La Carte et le territoire, p. 265 and p. 266.
} 
watch on television. Similarly, in Les Particules élémentaires, none of the middle-class characters engage in political activity, with the small exception of Annabelle's brother, a businessman in difficulty, “(qui) se consolait de ses soucis en buvant du pastis et en votant Le Pen". ${ }^{39}$ If the novel is a gossamer-veiled assault on his own mother, the real Lucie Ceccaldi's communist activism in Algeria (alongside Henri Alleg, author of La Question) gets no mention. The whole left-right divide, which had structured French political life and inspired intellectuals' heroic prises de position, is ridiculed in Bruno's farewell rant about measures by ecologists (Houellebecq's biggest political bugbear) to protect terns nesting on his favourite nudist beaches at Cap d'Agde : "Il veulent nous empêcher de partouzer et de manger du fromage de brebis, c'est des vrais nazis. Les socialistes sont complices. Ils sont contre les brebis parce que les brebis sont de droite alors que les loups sont de gauche ; pourtant les loups ressemblent aux bergers allemands, qui sont d'extrême droite. A qui se fier?". ${ }^{40}$

But communist affinities of sorts do run through Les Particules élémentaires, although Houellebecq's refusal of freedom, movement and desire place him firmly in opposition to the esprit de 68. The loi Neuwirth of 1967, legalising the contraceptive pill, triggers another destructive advance for US-inspired materialist individualism: "le couple et la famille représentaient le dernier îlot de communisme primitif au sein de la société libérale. La libération sexuelle eut pour effet la destruction de ces communautés intermédiaires, les dernières à séparer l'individu du marché. Ce processus de destruction se poursuit de nos jours". ${ }^{41}$ For the main characters, May 68 is not a time of liberation or romantic struggle on the barricades, or the final realisation of the groupe-en-fusion theorised by Sartre in Critique de la raison dialectique: in March of that year, Bruno Clément is brutally humiliated by his boarding-schoolmates, confirming in the eyes of hall subwarden Jean Cohen the dangers

\footnotetext{
${ }^{39}$ Les Particules élémentaires, p. 233.

${ }^{40}$ Ibid, p. 253.

${ }^{41}$ Ibid, p. 144.
} 
inherent in Nietzschean hedonism; while December sees the death of Michel Djerzinski's beloved grandmother, embodiment of working-class communist and female altruism. If anything, l'esprit de 68 is mocked in Houellebecq's description of "L'espace du possible", a New Age campsite that inexorably sheds its revolutionary pretensions and orients itself towards training sessions for businessmen. Instead, thanks to his scientific research, Michel Djerzinski - who shares the surname of the founder of the Soviet secret police - carries out a Stalinistic transformation of mankind, opening the way to a post-human sexual communism. In a long interview with Les Inrockuptibles, Houellebecq welcomed his accidental choice of the name Djerzinski, then displayed a particular brand of communist tradition :

On me l'a signalée, cette référence stalinienne. Je dois dire que j'ai trouvé plutôt bien : c'est un personnage assez sympathique : rajouter une petite couche stalinienne, ça peut lui donner une aura positive... Bon, c'est vrai, j'aime bien Staline (rires)... Parce qu'il a tué plein d'anarchistes (rires)... Parce qu'il a été assez sévère avec les trotskistes, deux mesures nécessaires pour éviter les déviations dangereuses. ${ }^{42}$

Houellebecq also believed that history would prove right Georges Marchais, the recentlydeceased general secretary of the PCF, on his assessment that "le bilan de l'URSS est globalement positif" and his approval of the Soviet intervention in Afghanistan : "l’URSS apportait néanmoins le progrès à une civilisation moyenâgeuse. Il suffit de voir ce qui se passe aujourd'hui en Afghanistan pour constater qu'il n'avait pas tout à fait tort" ${ }^{\prime 43}$. That said, Houellebecq reiterated his belief that Stalin and his comrades had failed to solve the questions of religion and morality, which remained essential to all successful societies, as his positivist hero Auguste Comte had warned.

\footnotetext{
42 «En finir avec le désir », Les Inrockuptibles, 19 August 1998, p. 20.

${ }^{43}$ Ibid, p. 20.
} 
In Houellebecq's work after Les Particules élémentaires, there is a reconciliation with, or at least a resignation to, the market, which can be seen to reflect the post-communist ideological and economic settlements, as well as his own new-found celebrity and wealth. Plateforme explores sex tourism as a possible solution for a western civilisation riddled by sexual misery, and, as proposed in the aforementioned interview with Les Inrockuptibles, Houellebecq imagines Castroist Cuba as one site for a chain of erotic hôtels de charme, Eldorador Aphrodite. But Houellebecq's vision of Cuba is far from the revolutionary ideal of old that had inspired Sartre and reinforced his very un-Houellebecquian belief in the purifying force of political violence. On inspecting a possible site for sex tourism, the narrator sees a gigantic and dilapidated brick factory that literally oozes Communist failure : "Sur le bas-côté, un panneau de métal où Che Guevara exhortait les travailleurs au développement des forces productives commençait à rouiller, lui aussi”. ${ }^{44}$. Deprived of the USSR's logistical support, “ce régime touchait aujourd'hui à sa fin". ${ }^{45}$ The old manager of the hotel the narrator and Valerie plan to transform, expresses disillusionment : "Pauvre peuple cubain... Ils n'ont plus rien à vendre, à l'exception de leurs corps". ${ }^{46}$ This broken hero of the Revolution remarks: "Nous avons échoué... et nous avons mérité notre échec. Nous avions des dirigeants de grande valeur, des hommes exceptionnels, idéalistes, qui faisaient passer le bien de la patrie avant leur intérêt propre". But the workers were unworthy of these leaders : “J'ai passé des années à essayer de leur parler, de les convaincre de se donner un peu plus de mal dans l'intérêt de leur pays : je n'ai connu que la déception et l'échec". ${ }^{47}$

Cuba therefore illustrates Houellebecq's general critique of real existing socialism: the failure to promote altruism and a revolutionary myth that might bring together society.

\footnotetext{
${ }^{44}$ Houellebecq, Plateforme (Paris : Flammarion, 2001), p. 239.

${ }^{45}$ Ibid, p. 246.

${ }^{46}$ Ibid, p. 247.

${ }^{47}$ Ibid, p. 247-8.
} 
Instead, capitalist materialism, here commodifying the bodies of the Third World in the form of sex tourism, seems more natural and destined for success. The only real threat to this 'ideal exchange' comes in the form of radical islam, responsible for the murder of the narrator's father at the beginning of Plateforme, then for the massacre perpetrated at the opening of the Eldorador Aphrodite chain in Thailand. Here Houellebecq seemed to offer a new, controversial aspect of his world-view, which chimed more with the concerns of the identitarian right.

In La Possibilité d'une île, Houellebecq evoked a generational movement away from any opposition to market economics. If the generation of main character Daniell had been familiar with debates about the merits and demerits of the market economy, such debates had disappeared for the generation of his young Spanish lover, Esther: "Le capitalisme était pour elle un milieu naturel (...) une manifestation contre un plan de licenciements lui aurait paru aussi absurde qu'une manifestation contre le rafraîchissement du temps, ou l'invasion de l'Afrique du Nord par les criquets pèlerins". ${ }^{48}$ From now on, more and more men and women were going to want to live “dans la liberté, dans l'irresponsabilité, dans la quête éperdue de la jouissance (...) La sociabilité avait fait son temps". ${ }^{49}$

In his exchange of letters with fellow "public enemy” Bernard-Henri Lévy - an ironic choice of correspondent given the latter's Sartrean pretensions as intellectuel engagé Houellebecq returned to the communist affinities of the grand-parents who had brought him up in the absence of his hippie, gauchiste mother and father. For Houellebecq, they voted communist for class reasons, and not due to any knowledge of Marx, Lenin or Thorez. Once his own father moved out of the working class, he lost all interest in politics, and with Houellebecq, this regrettable but inexorable process of de-politicisation had been confirmed and consolidated: "En ma personne nous sommes déjà en présence de la deuxième génération

\footnotetext{
${ }^{48}$ Houellebecq, La Possibilité d'une île (Paris : Fayard, 2005), p. 192-193.

${ }^{49}$ Ibid, p. 419-420.
} 
d'athées absolus - athées non seulement religieux, mais politiques". ${ }^{50}$ This disenchantment of and with the political world were expressed more forcefully in regards to his estranged mother: "Dans le parcours éclaté, absurde de Lucie Ceccaldi”, which "zapped" from communism to islam through various ideological and spiritual conversions, her son saw "quelque chose de terriblement, d'atrocement contemporain". 51

One last spasm of communist sympathy can be found in La Carte et le territoire. The artist Jed Martin, in his wish to be useful, is attracted to industry and artisanat, and his hero (as for his architect father and Houellebecq himself) is William Morris, who sought to abolish distinctions between manual and intellectual labour. That said, capitalist reality seems to have thwarted the dream of Morris (and his guru Marx) of having the proletariat work and live in the midst of beauty. At the end of another long, wine-soaked conversation, it is concluded: “A l'exception de la firme fondée par William Morris on ne peut citer qu'une succession d'échecs. Sans même parler des sociétés communistes, plus tard [...] Ce qu'on peut sans doute dire, c'est que le modèle de société proposé par William Morris n'aurait rien d'utopique où tous les hommes ressembleraient à William Morris" ${ }^{52}$. Bruno Viard is therefore justified in concluding that, "l'altruisme déçu" [his emphasis] is "la tendance politique profonde de $\mathrm{MH}^{\prime 53}$. Hence, in his most recent poetry collection, Configurations $d u$ dernier rivage, Houellebecq could make this disabused assessment of his fellow men: "Les hommes cherchent uniquement à se faire sucer la queue/Autant d'heures dans la journée que possible/Par autant de jolies filles que possible". 54

\section{Abstention from the Domain of the Struggle?}

\footnotetext{
${ }^{50}$ Houellebecq and Bernard-Henri Lévy, Ennemis publics (Paris : Flammarion, 2008), p. 174.

${ }^{51}$ Ibid, p. 198.

${ }^{52}$ La Carte et le territoire, p. 271.

${ }^{53}$ Bruno Viard, Houellebecq au laser. La faute à Mai 68 (Nice: Les éditions Ovadia, 2008), p. 43.

${ }^{54}$ Houellebecq, Configurations du dernier rivage (Paris: Flammarion, 2013), p. 46.
} 
De-politicisation and de-communisation do not, however, lead Houellebecq to disengage from the world and its vicissitudes. Islam has been the subject of some of his most controversial interventions. This should not come as a surprise, but Houellebecq's pied noir, like his communist, origins have been over-looked by critics. The former origins are hinted at in Les Particules élémentaires. Janine Ceccaldi is from French Algeria, and soon after his birth, Bruno is handed into the care of his grandmother in Algiers. They are then exiled to Marseilles, where the grandmother repeats to herself: “'L'Algérie, c'est la France...’ [...] Elle marchait de long en large entre les deux pièces, sa tête observant un point invisible. 'La France... La France...' répétait sa voix lentement décroissante". ${ }^{55}$ Here Bruno’s grandmother represents not just the world-defeat of feminine altruism, but also the loss of part of France that anticipates the loss of the whole.

Right from his first novel (though not in his poetry), the Arab, and by association the muslim population, is presented as a threat, an object of fear and resentment. This view is confirmed in Les Particules élémentaires then takes centre-stage in Plateforme and his controversial promotional interview with Lire. ${ }^{56}$ In "Europe Endless", he also denounced prime minister Lionel Jospin, who, shocked by hooliganism at a France-Algeria football "friendly", was "incapable de mater les sauvageons [...] à quoi bon payer les frais d'entretien d'un gouvernement s'il s'avère impossible de vivre en sécurité à l'intérieur des territoires qu'il contrôle ?". 57

For a decade, however, Houellebecq's work and public interventions skirted around the islam issue, with the exception of a brief passage in La Possibilité d'une île which evoked massive muslim immigration in Europe, and the adoption of islam by masochistic natives. ${ }^{58}$ This theme of "collaboration" became more explicit during a visit to Israel in 2011, where he

\footnotetext{
${ }^{55}$ Les Particules élémentaires, pp. 40-41.

56 “Michel Houellebecq", Lire, September 2001, pp. 28-36.

57 "Europe Endless", p. 1.

${ }^{58}$ La Possibilité d'une île, pp. 357-358.
} 
accused his bête noire, the ecologists, of "collaboration" with Islamism. ${ }^{59}$ Another anticipatory hint came in his interview with Beigbeder for Lui in 2014: "Je suis triste de l'état de mon pays. Tu veux que je te dise ? Je redoute une guerre civile". ${ }^{60}$ That said, in this interview, his political preoccupations could be seen as classically Houellebecquian and echoing the fictional and non-fictional interventions of his neo-Sartrean interlocutor: the main threat to civilisation came from a gauche morale that would criminalise prostitutes' clients and even ban smoking in your own home. Then, adopting a "ton gaullien", Houellebecq outlined his project for a new democratic constitution:

J'en ai parlé à Sarkozy, pour qui j'ai une réelle affection... eh bien, je souhaite généraliser la démocratie directe en supprimant le Parlement. A mon avis, le président de la République doit être élu à vie mais instantanément révocable sur simple référendum d'initiative populaire. Troisième mesure importante : la fonction de juge deviendra élective (...) Quatrième mesure : le budget de l'Etat sera décidé par les citoyens qui devront chaque année remplir une feuille avec des cases à cocher. Le peuple décidera ainsi quelles dépenses il juge prioritaires. On fera une moyenne avant d'allouer les budgets à chaque ministère. Il faut plus de démocratie directe si l'on veut sortir de cette crise de la représentation politique dans laquelle nous sommes. Si l'on n'adopte pas ces mesures, on court à la catastrophe (...) Rousseau avait élaboré un projet de Constitution pour la Pologne. Ceci est mon "projet pour la France". ${ }^{61}$

With its references to De Gaulle, Rousseau and Sarkozy, and in the context of a glossy men's magazine resurrected from the 1970s, adorned with photos of Russian models and adverts for

\footnotetext{
59 “'Houellebecq accuse les écologistes de ‘collaboration' avec l'islamisme”, Libération, 4 April 2011.

${ }^{60}$ Houellebecq : "Mon projet pour la France", Lui, 7, 2014, p. 24.

${ }^{61}$ Ibid. p. 24.
} 
luxury watches, this was a typically provocative and second degré approach to politics and the role of the intellectual. Houellebecq's proposals were also consistent with his aversion to parliamentary politics and his view of the citizen as tax-payer and usager.

The tone would change utterly, however, with the detonation of Soumission on the day of the Charlie-Hebdo massacre. This novel shows a further step away from Houellebecq's communist past, while showing his continuing preoccupation with religion. Here, a majority of the French electorate acquiesces to a President, Mohamed Ben Abbès, who is leader of the "moderate islamist" Fraternité musulmane. This organisation partly draws inspiration from what was once France's first political party: "Sur le modèle des partis musulmans à l'œuvre dans les pays arabes, modèle d'ailleurs antérieurement utilisé en France par le Parti communiste, l'action politique proprement dite était relayée par un réseau dense de mouvements de jeunesse, d'établissements culturels et d'associations caritatives" ${ }^{\text {"62 }}$. But this Fraternité musulmane is "un parti pas comme les autres" because it does not place the economy at the centre of everything. Unlike his old rival Tariq Ramadan, who had compromised himself by forming alliances with Trotskyists, Mohamed Ben Abbès had always avoided the anticapitalist left : "la droite libérale avait gagné la 'bataille des idées', il l'avait parfaitement compris, les jeunes étaient devenus entreprenariaux, et le caractère indépassable de l'économie de marché était à présent unanimement admis". ${ }^{63}$ It was on the level of values, and not the economy, that elections would be won or lost. In the presidential elections of May-June 2022, it becomes clear that the old centre-right/centre-left divide has collapsed, leaving islamists and the FN and identitaires as the main rivals, the Gaullists and the Communists now consigned to the distant margins. Robert Rediger, identitaire turned islamist President of the Islamic university of Sorbonne-Nouvelle, explains thus what is at stake :

\footnotetext{
${ }^{62}$ Houellebecq, Soumission (Paris : Flammarion, 2015), pp. 51-52.

${ }^{63}$ Ibid, p. 153.
} 
Tout le débat intellectuel du XXe siècle s'était résumé en une opposition entre le communisme - disons, la version hard de l'humanisme - et la démocratie libérale - sa variante molle ; c'était quand même terriblement réducteur. Le retour du religieux, dont on commençait alors à parler, je le savais pour ma part dès l'âge de quinze ans, je crois. ${ }^{64}$

In the space of a few decades, Europe, once the height of civilisation, had committed suicide. At the end of the novel, the narrator François seems to go with the flow of mass conversion to islam, although the concluding succession of sentences in the conditional tense suggests that this may well be yet another impasse. After all, it appears that religion has been manipulated for political and personal ends.

Now under police protection, Houellebecq did not make a pronouncement on the Charlie-Hebdo attack, only attending the funeral of one of the victims, Bernard Maris. However, the attacks of 13 November 2015 made him break his silence in an excoriating "J'accuse" published in Il Corriere della Sera two days later. Houellebecq praised a certain French spirit of resistance, while regretting the absence of a Winston Churchill at the helm. But if he did not mention islam in this polemic, he violently attacked the governing elite, beginning with François Hollande and Manuel Valls :

[L]a situation regrettable dans laquelle nous nous trouvons doit être attribuée à des responsabilités politiques spécifiques ; et ces responsabilités politiques devront tôt ou tard être étudiées à la loupe. Il est très improbable que l'insignifiant opportuniste qui occupe le fauteuil de chef de l'Etat, tout comme l'attardé congénital qui occupe les

\footnotetext{
${ }^{64}$ Ibid, pp. 253-254.
} 
fonctions de Premier ministre, pour ne rien dire des ténors de l'opposition (LOL) sortent avec les honneurs d'un tel examen.

The political class stood accused of non-assistance à un peuple en danger :

Qui a décidé les coupes dans les forces de police, jusqu'à réduire ces dernières à l'exaspération, [ à les rendre ] quasiment incapables d'effectuer leurs missions ? Qui, pendant des années, nous a répété que les frontières sont une antique absurdité, symbole d'un nationalisme dépassé et nauséabond? Il ne faut pas longtemps pour comprendre que ces responsabilités ont été largement partagées.

With the exception of Dominique de Villepin, French political leaders had committed France to absurd and costly operations in Iraq, Libya and Syria which only sowed chaos. He concluded:

Les gouvernements qui se sont succédé au cours des dix (vingt ? trente ?) dernières années ont failli péniblement, systématiquement, lourdement, dans leur mission fondamentale qui consiste à protéger la population française dont ils ont la charge (...). On pourrait multiplier à l'infini les exemples de la fracture - aujourd'hui abyssale - qui existe entre les citoyens et ceux qui devraient les représenter.

Such a crisis of representation was another confirmation of the need, already set out lightheartedly in Lui, for direct democracy à la suisse. ${ }^{65}$ Houellebecq's fulminations about

\footnotetext{
65 “Attentati Parigi, Houellebecq: 'Io accuse Hollande e difendo I francesi'”, Il Corriere della Sera, 15 November 2015. French translations quoted from https://www.lesechos.fr/19/11/2015/lesechos.fr/021492080735 apres-les-attentats-a-paris--le--j-accuse--demichel-houellebecq.htm [accessed 14 June 2018].
} 
growing insecurité also echoed the narrator's twist on Sartre at the beginning of Plateforme: "La gendarmerie est un humanisme". ${ }^{66}$

Houellebecq's evident islamophobia, obsession with law and order, attachment to national frontiers and penchant for referenda - he welcomed the Brexit vote of June 2016 and looked forward to a "Frexit" $"$ - could have made him an ideal compagnon de route for the Front national as it sought to break out of its own counter-cultural ghetto. However, he did not express public support for Marine Le Pen's candidacy in 2017. But he did not remain silent on French politics and was twice invited onto France 2 by his favourite television news presenter, David Pujadas. Houellebecq insisted that he was abstaining in the presidential elections. In fact, he revealed that the only presidential candidate he had ever voted for was Edouard Balladur, in 1995, because, typically, the then prime minister had shown reassuring sang-froid during a hijacking crisis. The author confessed to Pujadas that he did not know the peripheral "deuxième France", which had voted for Le Pen, describing this as "une faute professionnelle grave". "J'ai perdu le contact", he said. "Je ne pourrais pas écrire sur elle [...] Je fais partie de l'élite mondialisée, maintenant". This peripheral France "n'habite pas à Paris. À Paris, Le Pen n'existe pas. Elle existe dans des zones mal connues”. The Le Pen vote was not an ideological one, but, as with his communist grand-parents, un vote de classe.

Observing a France cut politically into four pieces, he remarked : "Je suis trop riche pour voter Le Pen ou Mélenchon et je ne suis pas un héritier pour voter Fillon”. But he would not vote for the middle-class "thérapie de groupe" embodied by Emmanuel Macron, remaining faithful to his policy of only voting in referenda. Concerning France's future in a globalised world, it lay in "de l'artisanat, de la gastronomie, du tourisme", as already imagined in $L a$

\footnotetext{
${ }^{66}$ Plateforme, p. 20.

${ }^{67}$ Nicolas Gary, "Selon Houellebecq, 'la France est très proche d'une sortie de l'Europe”, ActuaLitté, 16 November 2016, https://www.actualitte.com/article/monde-edition/selon-houellebecq-la-france-est-tres-proched-une-sortie-de-1-europe/67998 [accessed 16 July 2018]
} 
Carte et le Territoire. Such riches were not délocalisables, unlike the Whirlpool factory, which, after receiving state subsidies, was now being moved to Poland. ${ }^{68}$

Such concerns were developed in Houellebecq's essay on Donald Trump for Harper's. If the US President was “an appalling clown for a leader”, he nevertheless was withdrawing his troops from disastrous foreign adventures. Houellebecq also shared his hostility to the European Union and support for Brexit: "Europe is just a dumb idea that has gradually turned into a bad dream". Linked to this was Trump's nationalism and robustly protectionist defence of the interests of American workers against the threat posed by global free trade. ${ }^{69}$ This article coincided with the publication of Houellebecq's novel, Sérotonine, which, while repeating obsessive concerns about ageing, sexual loneliness, the vanquished white male and the barbaric role of anti-smoking legislation, also provided political comment. The narrator, a depressed agronomist, observes the relative pauperisation of the middle classes, the fear of déclassement among university undergraduates, and, above all, the crisis facing the last remnants of the French paysannerie, threatened by la grande distribution, the European Union and globalisation. After his student friend and fellow Normandy dairy farmers perish in a clash with the authorities (partially echoing the gilets jaunes protests), the narrator's remarks on the political fallout indicate the persistent political ambivalence of Houellebecq:

Le scandale de la suppression des quotas laitiers revenait comme un impensé obsédant, coupable, dont personne ne parvenait tout à fait à s'affranchir, seul le Rassemblement national semblait tout à fait clair sur le sujet. Les conditions insupportables que la grande distribution faisait peser sur les producteurs étaient elle

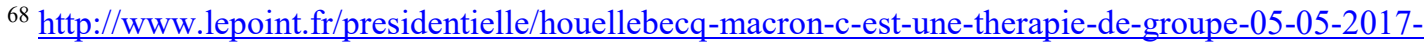
2125116 3121.php [accessed 14 June 2018].

${ }^{69}$ Houellebecq, "Donald Trump is a good President. One foreigner's perspective", Harper's, January 2019, https://harpers.org/archive/2019/01/donald-trump-is-a-good-president/ [accessed 15 January 2019].
} 
aussi un sujet honteux, que chacun, à part peut-être les communistes - j’appris en cette occasion qu'il existait encore un Parti communiste - préférait essayer d'éluder. ${ }^{70}$

\section{Situation of Michel Houellebecq}

In the concluding part of Qu'est-ce que la littérature?, "Situation de l'écrivain en 1947”, Jean-Paul Sartre wrote: "Rien ne nous assure que la littérature soit immortelle ; sa chance, aujourd'hui, son unique chance, c'est la chance de l'Europe, du socialisme, de la démocratie, de la paix". ${ }^{71}$ If literature has defied mortality since 1947, its Sartrean horizon has changed dramatically from the mixture of danger and opportunity offered by the onset of the Cold War and the beginnings of les Trente glorieuses. In 2004, Michel Houellebecq had remarked to Bernard-Henri Lévy on how the situation had changed from that enjoyed by his miserabilist and contrarian predecessors: "La France des années 1950 supportait sans broncher des gens comme Camus, Sartre, Ionesco ou Beckett. La France des années 2000 a déjà du mal à supporter des gens comme moi". ${ }^{72}$ But in the contemporary context of the crisis of the European Union, the collapse of social democracy and the rise of "national-populism", the migrant crisis and the war on terror, Houellebecquian engagement could be considered particularly apposite. Globalised yet Gallic, now far from the heroic period of the universal intellectual, Houellebecq observes and comments, rarely without humour, on his own situation: the ungraspable "totality" of an atomised and enclaved society, marked by a crisis of political representation and stratification by education and income, all soaked in a climate of fear.

\footnotetext{
${ }^{70}$ Houellebecq, Sérotonine (Paris : Flammarion, 2019), p. 265.

${ }^{71}$ Sartre, p. 356.

${ }^{72}$ Ennemis publics, p. 71.
} 


\section{The Author}

Gavin Bowd,

School of Modern Languages,

University of St Andrews,

KY16 9PH,

UK

e-mail: gpb@st-andrews.ac.uk 


\section{Author}

Gavin Bowd,

Reader in French, University of St Andrews, UK

gpb@st-andrews.ac.uk 